\title{
Light and nutrient effects on microbial communities collected during spring and summer in the Beaufort Sea
}

\author{
M. Estrada ${ }^{1, *}$, M. Bayer-Giraldi ${ }^{1,3}$, J. Felipe ${ }^{1}$, C. Marrasé $^{1}$, M. M. Sala ${ }^{1}$, M. Vidal ${ }^{2}$ \\ ${ }^{1}$ Institut de Ciències del Mar, CSIC, Pg. Marítim de la Barceloneta 37-49, 08003 Barcelona, Spain \\ ${ }^{2}$ Departament d'Ecologia, Universitat de Barcelona, Avgda. Diagonal 645, 08028 Barcelona, Spain \\ ${ }^{3}$ Present address: Alfred-Wegener-Institute for Polar and Marine Research, Postfach 120161, 27515 Bremerhaven, Germany
}

\begin{abstract}
Between autumn 2003 and summer 2004, the icebreaker CCGS 'Amundsen' occupied a station in Franklin Bay, Beaufort Sea. Two microcosm experiments were carried out in spring, while the water column was covered by sea ice, to test whether phytoplankton assemblages sampled from ice-covered (spring) surface waters would be able to bloom when exposed to increased light and to what extent this bloom would be limited by light or nutrients. Two additional experiments were carried out during a sea-ice free period in summer. For the spring experiments (April 2004), surface water collected through an ice hole was distributed into $10 \mathrm{l}$ Nalgene bottles and subjected to different photosynthetically available radiation ( $\mathrm{PAR}_{;} 5$ to $60 \mu \mathrm{mol}$ photons $\mathrm{m}^{-2} \mathrm{~s}^{-1}$ ) and nutrient addition treatments. A similar setup was repeated in July and August 2004. In the spring experiments, chlorophyll a $(\mathrm{chl}$ a) concentration showed an initial decline, probably reflecting a combination of autotrophic cell losses and photoacclimation effects. After about $2 \mathrm{wk}$, chl a started to increase exponentially at PAR above $10 \mu \mathrm{mol}$ photons $\mathrm{m}^{-2} \mathrm{~s}^{-1}$, due to the proliferation of autotrophic nanoflagellates. In summer, chl a increased immediately after enclosure, mainly due to diatom (Thalassiosira/ Porosira) growth. In spring, nutrient addition had no effect on the net rate of chl a accumulation, while phytoplankton increased faster and reached higher biomass in the nutrient-amended bottles in summer. The relationships between nutrient consumption and production of $\mathrm{chl} a$ and particulate organic matter in our experiments suggested an important utilization of dissolved organic nutrients.
\end{abstract}

KEY WORDS: Phytoplankton · Protists · Nutrients · Stoichiometry $\cdot$ Light response $\cdot$ Sea ice · Beaufort Sea · Arctic

\section{INTRODUCTION}

A key ecological feature of polar marine environments is their strong seasonality. Phytoplankton at high latitudes experience long periods of alternating dark and light conditions. Another important ecological feature is the presence of sea ice during a large part of the year. Some observations indicate low phytoplankton biomass (Rysgaard et al. 1999) and limited bacterial metabolic activity during the winter period (Anderson \& Rivkin 2001). However, recent research has suggested that the microbial food web can remain highly dynamic in winter (Anderson \& Rivkin 2001, Wells \& Deming 2006, Sala et al. 2008).

Information on planktonic community structure during the Arctic winter is sparse. During this period, phytoplankton appear to be mainly represented by flagellates (Horner \& Schrader 1982), particularly by picoeukaryotes of the genus Micromonas and unidentified haptophytes (Lovejoy et al. 2007), although phytoplankton from other groups, including diatoms and pigmented dinoflagellates, can also be found (Sherr et al. 2003). As in other marine areas, seasonal blooms develop when increased insolation and vertical 
stratification allow a net positive algal growth. In general, microalgae proliferate in spring, starting with the under-ice communities and continuing with those of the water column, when the ice breaks up in spring/early summer (Sherr et al. 2003, Wang et al. 2005). Diatoms are major contributors to the spring bloom in many Arctic regions, including that in the Beaufort Sea (Hsiao et al. 1977, Longhurst 1998, von Quillfeldt 2000, Booth et al. 2002, Lovejoy et al. 2002, Hill et al. 2005), but other taxa (e.g. Phaeocystis) may reach high abundance in some areas (Gradinger \& Baumann 1991, Smith et al. 1991). At certain times of the year, Micromonas and other flagellates may also be important (Sherr et al. 2003, Lovejoy et al. 2007).

Initiation of phytoplankton growth after the winter period in the central Arctic Ocean appears to follow increased insolation due to melting of snow and sea ice (Horner \& Schrader 1982), although the concomitant increase in surface temperature and the release of ice algae into the water column may confound the relationships between the timing of phytoplankton growth and light conditions (Tremblay et al. 2006). Thereafter, phytoplankton development leads to macronutrient depletion that limits further growth (Gradinger \& Baumann 1991, Sherr \& Sherr 2003, Carmack et al. 2004). Another interesting feature of polar blooms is the possible departure of their carbon (C) yield with respect to inorganic nutrients from Redfield stoichiometry (Tremblay et al. 2006) due to processes like the uptake or release of dissolved organic nitrogen (DON) by phytoplankton (Kattner \& Becker 1991, Hu \& Smith 1998).

As part of the Canadian Arctic Shelf Exchange Study (CASES), the CCGS 'Amundsen' was frozen into the ice in Franklin Bay (Beaufort Sea) during fall 2003, remained there until ice melting the following spring, and sampled the same region until summer 2004. This strategy afforded the opportunity to investigate temporal variations in phytoplankton response to forcing factors such as light or nutrient availability. In the present experimental study, we examined (1) whether phytoplankton cells sampled from ice-covered (spring) surface waters would be able to bloom when exposed to increased light, and (2) to what extent the growth of phytoplankton communities from ice-covered (spring) waters would be limited by light or nutrients. We also aimed to characterise the composition of the resulting phytoplankton assemblages and the changes in the concentrations of heterotrophic protists, as well as check whether the changes in inorganic nutrients and particulate organic matter followed classical Redfield stoichiometry. Additional experiments were carried out during summer to compare the response of the main microalgal groups and the stoichiometric changes after enclosure of communities from ice-free waters (summer) of the same area with those found in spring, and to verify whether the summer results were similar to those of enclosure experiments in temperate regions. In order to address these topics, we designed a series of microcosm experiments that were carried out on board the 'Amundsen' between April 2003 and August 2004 during legs 6, 8 and 9 of the CASES project. Our objectives were partly similar to those of Terrado et al. (2008), who carried out experiments during leg 6 of the project to determine the importance of light exposure and nutrients in controlling microbial dynamics during spring. However, the scope of both sets of experiments was different, as Terrado et al. (2008) emphasised the nutrient treatments and the changes between the initial and final communities, while our experiments included different light levels and aimed to characterise temporal changes in the main phytoplankton taxa.

\section{MATERIALS AND METHODS}

Experimental setup. Experiments were started on 4 occasions during legs 6 (April 2004), 8 (July 2004) and 9 (August 2004) of CASES (Table 1), while the 'Amundsen' was overwintering or visiting a station at $70^{\circ} 16.2^{\prime} \mathrm{N}, 126^{\circ} 10.8^{\prime} \mathrm{W}$ located in Franklin Bay. Duration of the experiments was constrained by the timing of the corresponding cruise legs. Water depth at the station was $250 \mathrm{~m}$. In situ water temperatures at the time of sampling are given in Table 1. Water was taken with a Niskin bottle either from $3 \mathrm{~m}$ below the ice-air interface (1.5 $\mathrm{m}$ below the ice bottom) at the so-called

Table 1. Starting dates, in situ water temperature, and initial nutrient and chl a concentrations for the different experiments

\begin{tabular}{|c|c|c|c|c|c|c|c|c|}
\hline \multirow[t]{2}{*}{ Expt } & \multirow{2}{*}{$\begin{array}{l}\text { Starting date } \\
\quad(2004)\end{array}$} & \multirow{2}{*}{$\begin{array}{c}\text { In situ water } \\
\text { temperature }\left({ }^{\circ} \mathrm{C}\right)\end{array}$} & \multicolumn{5}{|c|}{ Initial nutrient concentration $\left(\mathrm{mmol} \mathrm{m}^{-3}\right)$} & \multirow{2}{*}{$\begin{array}{c}\mathrm{Chl} \mathrm{a} \\
\left(\mathrm{mg} \mathrm{m}^{-3}\right)\end{array}$} \\
\hline & & & Phosphate & Ammonium & Nitrite & Nitrate & Silicate & \\
\hline E-spring1 & 6 Apr & -1.7 & 1.43 & 0.27 & 0.04 & 2.09 & 6.55 & 0.29 \\
\hline E-spring2 & 18 Apr & -1.7 & 0.92 & 0.15 & 0.02 & 1.37 & 6.02 & 0.33 \\
\hline E-summer1 & $17 \mathrm{Jul}$ & 4.0 & 0.34 & 0.18 & 0.02 & 0.16 & 6.02 & 1.48 \\
\hline E-summer2 & 12 Aug & 2.9 & 0.82 & 1.15 & 0.03 & 0.23 & 4.01 & 0.38 \\
\hline
\end{tabular}


Titicaca ice hole, located in the vicinity of the ship (spring experiments, E-spring1 and E-spring2), or from the sea surface (summer experiments, E-summer1 and E-summer2). The water was distributed (after prefiltration through a $200 \mu \mathrm{m}$ mesh net in E-spring 2 and without prefiltration in the others) into 6 (E-spring1 and E-summer1) or 3 (E-spring2 and E-summer2) 101 Nalgene bottles, which were placed in a chamber with controlled temperature close to that in situ $\left(0^{\circ} \mathrm{C}\right.$ in spring and surface water temperature, $4^{\circ} \mathrm{C}$ in $\mathrm{E}$ summer 1 and $3^{\circ} \mathrm{C}$ in E-summer2). During the spring leg, the Titicaca ice hole was permanently open, although a thin layer of surface water froze between samplings. We avoided touching the ice during sampling but cannot discount the possibility that some of the microalgae collected had previously been growing on the ice bottom; however, their influence must have been small, since Terrado et al. (2008) found similar autotrophic communities in samples taken from $10 \mathrm{~m}$ water depth through an opening from inside the ship. The prefiltration step in E-spring2 was adopted after observing an initial chlorophyll a ( $\mathrm{chl} a)$ decrease in Espring1, to avoid the potential effect of grazing by large zooplankton. As E-spring2 also showed an initial chl a decline, prefiltration was no longer used in further experiments.

Light and nutrient treatments. The bottles were illuminated with 3 pairs (1 Cool light +1 Gro-Lux) of fluorescent tubes. Lower light levels were obtained by covering the bottles with one or more layers of black gauze. Nutrients (nitrate, phosphate, silicate and a metal mix) were added to some of the bottles in experiments E-spring1, E-summer1 and E-summer2, to check for potential nutrient limitation. Details about light and nutrient treatments for each experiment are given below and summarized in Table 2. In April 2004, photosynthetically available radiation (PAR) reaching the ice surface ranged from 24 to $45 \mathrm{~mol}$ photons $\mathrm{m}^{-2}$ $\mathrm{d}^{-1}$ (R. Terrado pers. comm.). However, the estimated PAR at $3 \mathrm{~m}$ depth below the ice-air interface was $<1 \%$ of these values (R. Terrado pers. comm.). Between the beginning of July and the middle of August, incident PAR ranged from 20 to $50 \mathrm{~mol}$ photons $\mathrm{m}^{-2} \mathrm{~d}^{-1}$.

E-spring1: Two light and 2 nutrient levels were tested. Three of the bottles (L60 bottles) received PAR of $\sim 60 \mu \mathrm{mol}$ photons $\mathrm{m}^{-2} \mathrm{~s}^{-1}$ (from 04:30 to 23:30 h) and 3 (L30 bottles) were covered with black gauze to lower the illumination to $\sim 30 \mu \mathrm{mol}$ photons $\mathrm{m}^{-2} \mathrm{~s}^{-1}$ for the period from 11:30 to 15:30 $\mathrm{h}$ (the bottles were covered with black plastic bags during the remainder of the illumination cycle). Two of the L60 (L60_Na and L60_Nb) and 2 of the L30 (L30_Na and L30_Nb) bottles received nutrient additions at the following estimated final concentrations: $16 \mathrm{mmol}$ nitrate $\mathrm{m}^{-3}, 1 \mathrm{mmol}$ phosphate $\mathrm{m}^{-3}$, and $32 \mathrm{mmol}$ silicate $\mathrm{m}^{-3}$. A solution of metals was also added at the same ratio of nitrate:metals as in the f/2 medium of Guillard \& Ryther (1962). The third bottle of each of the L60 and L30 sets was left unmodified as a control (L60_C and L30_C, respectively). Final samples were taken from the 3 L60 bottles on Day 9. At this time, the L30 bottles were left unmodified but the light period was extended to last from 4:30 to 23:30 h.

E-spring2: Only the light gradient was manipulated. Three bottles were covered with black gauze to set the incident illumination to 17 (bottle L17), 10 (bottle L10) and 5 to $6 \mu \mathrm{mol}$ photons $\mathrm{m}^{-2} \mathrm{~s}^{-1}$ (bottle L5), between 4:30 and 23:30 h. The bottles were kept in the dark during the remaining time. No nutrients were added.

Table 2. Summary of the light and nutrient treatments used in the experiments. Nutrients were added at estimated final concentrations of $16 \mathrm{mmol}$ nitrate $\mathrm{m}^{-3}, 1 \mathrm{mmol}$ phosphate $\mathrm{m}^{-3}$, and $32 \mathrm{mmol}$ silicate $\mathrm{m}^{-3}$. A proportional amount of a metal solution according to the f/2 medium of Guillard \& Ryther (1962) was also added (see 'Materials and methods' for details). PAR: photosynthetically available radiation

\begin{tabular}{|c|c|c|c|c|c|c|}
\hline Expt & Treatment & $\begin{array}{l}\text { Replicates } \\
\text { (no.) }\end{array}$ & $\begin{array}{l}\text { Daylength } \\
\text { (h) }\end{array}$ & $\begin{array}{c}\text { Irradiance level } \\
\left(\mu \mathrm{mol} \text { photons } \mathrm{m}^{-2} \mathrm{~s}^{-1}\right)\end{array}$ & $\begin{array}{c}\text { Daily PAR } \\
\left(\mathrm{mol} \text { photons } \mathrm{m}^{-2} \mathrm{~d}^{-1}\right)\end{array}$ & $\begin{array}{l}\text { Nutrient } \\
\text { addition }\end{array}$ \\
\hline E-spring1 & L60_N & $2(\mathrm{a}, \mathrm{b})$ & 4 & 60 & 0.43 & Yes \\
\hline E-spring1 & L60_C & 1 & 4 & 60 & 0.43 & No \\
\hline E-spring1 & L30_N & $2(a, b)$ & $\begin{array}{c}4 \text { (for } 10 \mathrm{~d} \text { ) } \\
19 \text { (thereafter) }\end{array}$ & 30 & $\begin{array}{c}0.43(10 \mathrm{~d}) \\
2.05 \text { (thereafter) }\end{array}$ & Yes \\
\hline E-spring1 & L30_C & 1 & $\begin{array}{c}4 \text { (for } 10 \mathrm{~d} \text { ) } \\
19 \text { (thereafter) }\end{array}$ & 30 & $\begin{array}{c}0.43(10 \mathrm{~d}) \\
2.05 \text { (thereafter) }\end{array}$ & No \\
\hline E-spring2 & L17 & 1 & 19 & 17 & 1.16 & No \\
\hline E-spring2 & L10 & 1 & 19 & 10 & 0.68 & No \\
\hline E-spring2 & L5 & 1 & 19 & 5 & 0.34 & No \\
\hline E-summer1 & L60_N & $2(\mathrm{a}, \mathrm{b})$ & 19 & 60 & 4.78 & Yes \\
\hline E-summer1 & L30_C & 1 & 19 & 60 & 2.05 & No \\
\hline E-summer2 & L20_N & $2(\mathrm{a}, \mathrm{b})$ & 19 & 20 & 1.37 & Yes \\
\hline E-summer2 & L20_C & 1 & 19 & 20 & 1.37 & No \\
\hline
\end{tabular}


E-summer1: Two light and 2 nutrient levels were tested. This experiment was intended to repeat the light and nutrient treatments of E-spring1. However, due to the loss of some samples, only 3 of the bottles could be used. Two of these bottles (L60_Na and L60_Nb) received nutrients as those in E-spring 1 and were exposed to an irradiance of $60 \mu \mathrm{mol}$ photons $\mathrm{m}^{-2} \mathrm{~s}^{-1}$. The other bottle (L30_C) did not receive nutrients and was incubated under $30 \mu \mathrm{mol}$ photons $\mathrm{m}^{-2} \mathrm{~s}^{-1}$. The light period for all bottles lasted from 4:30 to 23:30 h. After $15 \mathrm{~d}$, final samples were taken from the 2 L60 bottles, while the L30_C bottle was left for 12 additional days.

E-summer2: One light and 2 nutrient levels were tested. Three bottles were covered with a single layer of black gauze, but due to a change in their location with respect to the lights, they received $\sim 20$ instead of $30 \mu \mathrm{mol}$ photons $\mathrm{m}^{-2} \mathrm{~s}^{-1}$ as in the L30 bottles of previous experiments. Therefore, the light treatment in this experiment was referred to as L20. Two of the bottles received nutrient additions as in E-spring1.

Sampling strategy. Samples for the measurement of major nutrients (nitrate, nitrite, ammonium, phosphate and silicate) and particulate organic carbon (POC), nitrogen (PON) and phosphorus (POP) concentrations were taken at the beginning and at the end of the experiments and preserved frozen until analysis after the cruise. Samples for the determination of chl $a$, picoeukaryotes (by flow cytometry), nanoflagellates (by epifluorescence microscopy) and phytoplankton (by inverted light microscopy) were taken every other day, but microscopic examinations were only carried out for a selected subset of samples from E-summer1 and E-summer2.

Analytical techniques. Nitrate, nitrite, ammonium, phosphate and silicate concentrations were determined using an Alliance Evolution II autoanalyser, following the methods of Grasshoff et al. (1999). Samples for POC, PON and POP analyses were immediately filtered through precombusted $\left(450^{\circ} \mathrm{C}, 2 \mathrm{~h}\right)$ Whatman GF/F filters. POC and PON were analysed in a CarloErba CHN analyser after thawing the filters in an atmosphere of $\mathrm{HCl}$ fumes to remove carbonate followed by drying at $60^{\circ} \mathrm{C}$. POP was determined spectrophotometrically following oxidation of the filter in acidic persulfate at $120^{\circ} \mathrm{C}$ for $0.5 \mathrm{~h}$ and subsequent analysis of dissolved phosphate (Grasshoff et al. 1999, Vidal \& Duarte 2000). For chl a measurement (Yentsch \& Menzel 1963), 175 to $200 \mathrm{ml}$ of water was filtered through Whatman GF/F filters, which were then placed in $90 \%$ acetone and stored in the dark in a refrigerator $\left(4^{\circ} \mathrm{C}\right)$ for $24 \mathrm{~h}$ to allow extraction. Fluorescence of the extracts was measured on board with a Turner Designs fluorometer.

Samples for flow cytometric counts (1.8 ml of water) were fixed with $180 \mu \mathrm{l}$ of $1 \%$ paraformaldehyde +
$0.05 \%$ glutaraldehyde (final concentrations), deep frozen in liquid nitrogen and stored at $-80^{\circ} \mathrm{C}$. For analysis, the samples were thawed and liquid subsamples of $200 \mu \mathrm{l}$ were drawn. To determine red fluorescent autotrophic 'picoeukaryotes' (size range 1.5-5 $\mu \mathrm{m}$, but mostly between 2-2.5 $\mu \mathrm{m}$ ), the unstained subsamples were processed in a FacsCalibur (Becton Dickinson) flow cytometer equipped with a laser emitting at $488 \mathrm{~nm}$. Fluorescent $0.96 \mu \mathrm{m}$ beads (Polysciences) of known density were added as internal standard. For enumeration of flagellates (hereafter 'nanoflagellates'), $50 \mathrm{ml}$ of water was fixed with $10 \%$ glutaraldehyde $(0.5 \%$ final concentration), filtered through $0.8 \mu \mathrm{m}$ pore size Nuclepore black polycarbonate filters and stained with DAPI ( $1 \mathrm{\mu g} \mathrm{l}^{-1}$ final concentration). The filters were then placed on glass slides with a drop of oil and a coverslip and stored frozen at $-20^{\circ} \mathrm{C}$ until analysis.

Autotrophic and heterotrophic nanoflagellates were counted with an epifluorescence microscope (Porter \& Feig 1980) and sorted into several major taxa and size classes. In the case of autotrophic (or phototrophic) flagellates, the lowest of these size classes $(2-5 \mu \mathrm{m})$ may present a variable overlap with the picoeukaryotes (hereafter 'autotrophic picoflagellates') determined by flow cytometry. In some samples, underestimation of cell concentrations might have occurred, particularly in the smallest size categories, due to fading of DAPI or chl a fluorescence in the preparations. Phytoplankton samples (50 ml) were preserved with a formalin-hexamine solution $(0.4 \%$ final concentration, Throndsen 1978). Cell counts of phytoplankton were obtained with an inverted microscope (Utermöhl 1958) using $50 \mathrm{ml}$ sedimentation chambers. One transect of the bottom of the chamber was scanned at high magnification $(600 \times)$ to count the most abundant forms. An additional transect and the whole chamber bottom were examined at $125 \times$ to count larger and rarer organisms.

\section{RESULTS}

\section{Community dynamics}

In E-spring1, chl a concentrations in all L60 and L30 bottles showed an initial decrease that lasted throughout the experiment (Fig. 1a). The rate of decrease was lower in the L30 bottles that were exposed to the lower irradiance than in the L60 bottles. While the L60 bottles were processed on Day 9, the L30 bottles were incubated further; here, the decrease in chl a concentrations continued until Day 15, after which chl a started to increase exponentially. No significant differences in chl a were found between nutrient 
treatments during the first $15 \mathrm{~d}$. Afterwards, chl a concentration became clearly higher in the nutrientenriched L30 bottles than in the control, although there were no apparent differences in the rate of chl a increase. The populations of autotrophic picoflagellates and of auto- and heterotrophic nanoflagellates decreased after enclosure in all bottles (Fig. 2, L60 and L30; Fig. 3, L30). The initial autotrophic community comprised small flagellates in the 2-5 $\mu \mathrm{m}$ size range, probably dominated by Micromonas sp. with an important contribution from haptophytes ( 3 to 4 $\mu \mathrm{m}$ in diameter). The haptophypes rapidly lost their chloroplast fluorescence, especially in the L60 bottles. In the L60 treatment, the autotrophic picoflagellates disappeared from the experimental vessels after $5 \mathrm{~d}$ (Fig. 2) while the nanoflagellates showed a short-lived peak around Days 3 to 7 (M. Estrada et al. unpubl. data). In the L30 bottles, the autotrophic picoflagellates and the different size classes of autotrophic nanoflagellates showed marked oscillations during the experiment (Figs. $2 \& 3$ ), which ended with high concentrations of the smaller size groups. When chl $a$ started to increase after the first 2 wk of the experiment, the autotrophic assemblage (Fig. 3) consisted mainly of small pico- and nanoflagellates $(<10 \mu \mathrm{m}$ in diameter), including an exponentially increasing number of Pyramimonas sp. ( 8 to $9 \mu \mathrm{m}$ in length).
Only a few scattered pennate diatoms could be seen in some samples.

In the 3 bottles of E-spring2 (Fig. 1b), chl a also decreased during the first 5 to $9 \mathrm{~d}$ at a rate comparable to that of the previous L30 series of E-spring1. Thereafter, chl a started to increase in the L17 and L10 bottles but remained approximately constant in the L5 bottles. Chl a concentration peaked on Day 17 in the L10 bottles, but continued to increase until the end of the experiment in the L17 treatments. The autotrophic picoflagellates (Fig. 2) increased shortly after enclosure and reached a maximum on Day 19, with highest concentrations in the L17 and lowest in the L5 treatments. The changes in the nanoflagellate population were similar to those described for comparable phases of the control L30 bottle of E-spring1. There was an initial decrease in heterotrophic nanoflagellates (Fig. 2d) and in some categories of phototrophic nanoflagellates (Fig. 4), followed by cell density fluctuations and a marked increase in heterotrophic nanoflagellates towards the last days of the experiment. In the L17 treatment, the concentrations of $2-5$ and $5-10 \mu \mathrm{m}$ autotrophic nanoflagellates also showed a marked peak at the end of the experiment, but the abundance of Pyramimonas sp. remained relatively low (Fig. 4d). As in E-spring1, pennate diatom cells were observed in some of the samples.

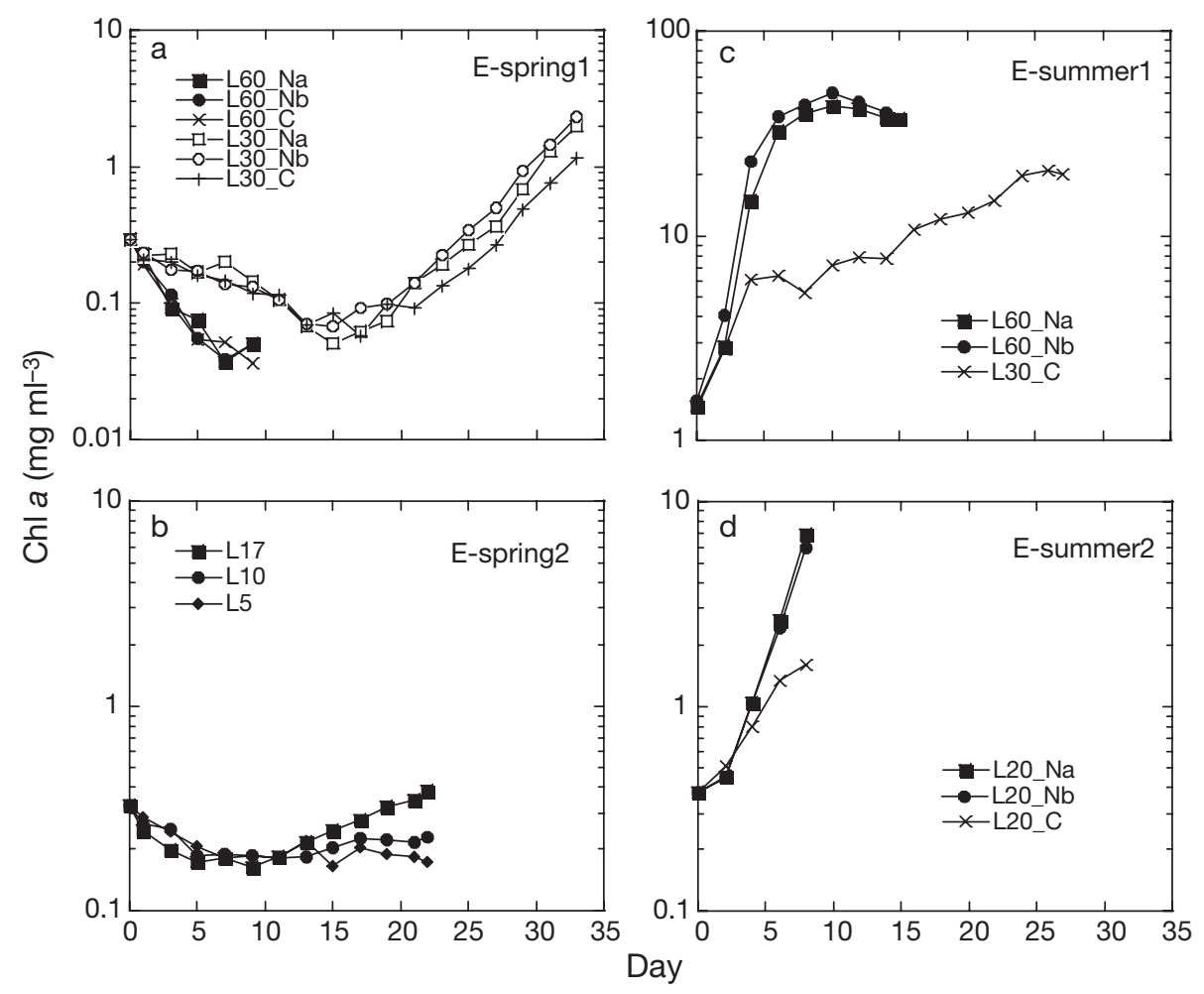

Fig. 1. Temporal evolution of chlorophyll a ( $\mathrm{chl}$ a) concentration in the 4 experiments: (a) E-spring1, (b) E-spring2, (c) E-summer1 and (d) E-summer2. Note the different scales. Treatment descriptions in Table 2 

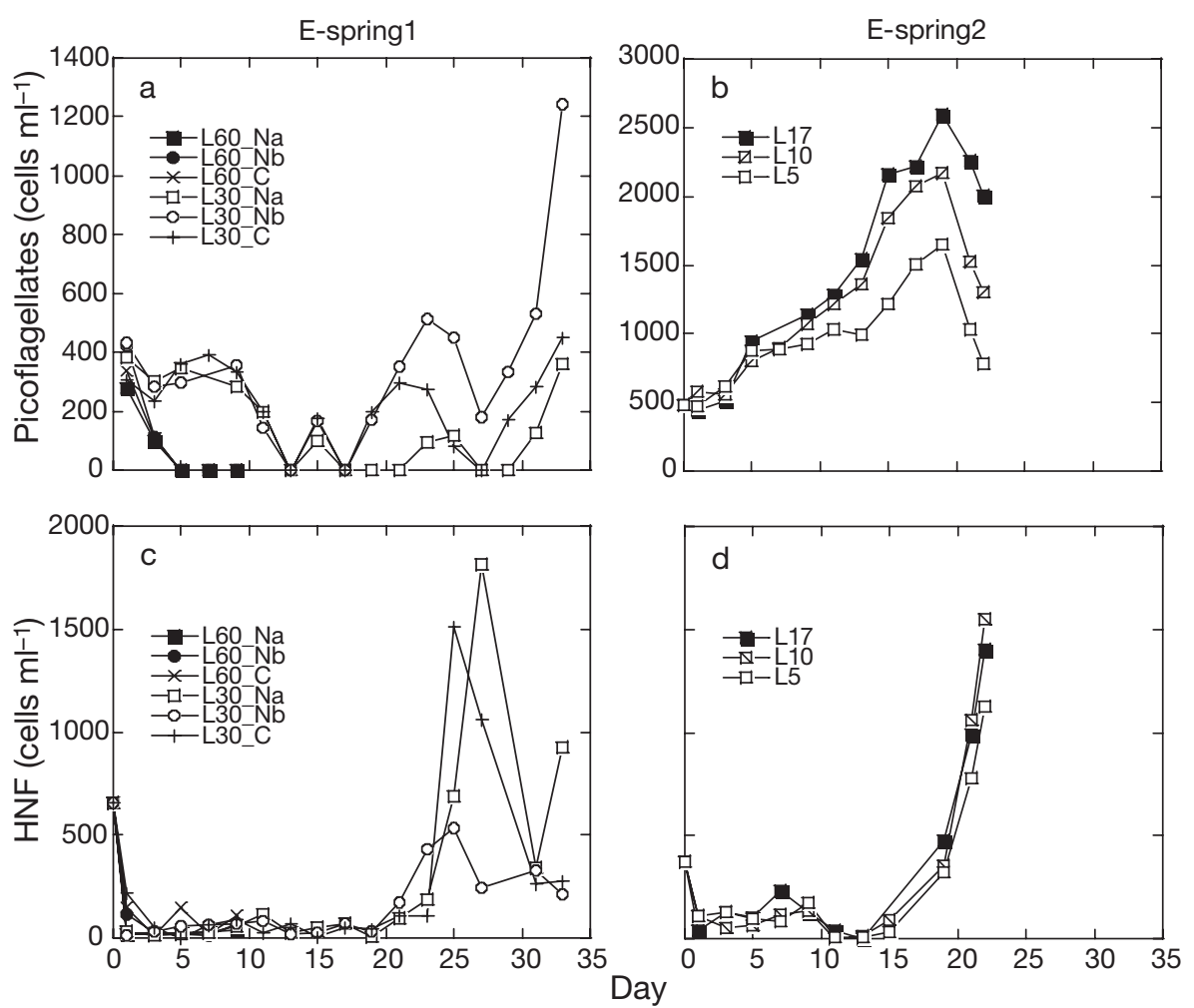

Fig. 2. Temporal evolution of $(\mathrm{a}, \mathrm{b})$ autotrophic picoflagellate and $(\mathrm{c}, \mathrm{d})$ heterotrophic nanoflagellate (HNF) abundances in the different microcosms of E-spring1 $(\mathrm{a}, \mathrm{c})$ and E-spring2 $(\mathrm{b}, \mathrm{d})$. See treatment descriptions in Table 2

Chl a concentration increased immediately after enclosure in all bottles of E-summer1 (Fig. 1c). In the L60_N bottles, chl a peaked around maximum values of 40 to $50 \mathrm{mg} \mathrm{m}^{-3}$ and started to decrease slowly until processing on Day 15. In the L30_C bottle, chl a increased exponentially at a relatively faster rate during the first $4 \mathrm{~d}$ and at a more variable and slower rate thereafter, reaching $20 \mathrm{mg} \mathrm{m}^{-3}$ at the end of the experiment. The rate of increase was stronger in the L60_N bottles than in the L30_C one, which had not received nutrients and was exposed to a lower irradiance. Autotrophic picoflagellates (Fig. 5a) peaked between Days 8 and 12 in the L60_N bottles, but showed only a small increase at the end of the experiment in the L_30 treatment. Nanoflagellates of 2-5 $\mu \mathrm{m}$ size, mostly composed of Micromonas sp., peaked around $4 \mathrm{~d}$ after enclosure in all bottles (Fig. 6) and were followed by haptophytes, Chaetoceros spp. and forms of the Thalassiosira/Porosira complex in the L60_N treatment (Fig. 6). The L30_C bottle also showed a 2-5 $\mu \mathrm{m}$ nanoflagellate maximum, but the diatom population peaked at much lower concentrations, probably due to exhaustion of nutrients and lower irradiance as well as the presence of a thecate amoeba similar to Difflugia (hereafter Dif- flugia sp.?) presumably feeding on the diatoms, as Thalassiosira/Porosira cells were seen inside many of the amoebae. In all bottles, heterotrophic nanoflagellates increased steadily throughout the experiment (Fig. 5a).

In E-summer2, chl a increased exponentially at a faster rate in the nutrient-enriched (L20_N) bottles than in the control (L20_C) after a short lag phase (Fig. 1d). The experiment had to be terminated before the end of the exponential phase in the L20_N bottles. The evolution of phytoplankton (Figs. $5 \mathrm{~b} \&$ \%) was similar to that in E-summer1, with a rapid increase in autotrophic picoflagellates and 2-5 $\mu \mathrm{m}$ nanoflagellates (mostly Micromonas spp.), and the development of a diatom population dominated by Chaetoceros spp. and Thalassiosira/Porosira. In contrast to E-summer1, heterotrophic flagellates varied little over the course of the experiment (Fig. 5).

\section{Nutrient stoichiometry}

A summary of the measurements of initial and final chl $a$, dissolved inorganic nitrogen (DIN $=$ nitrate + nitrite + ammonium), POC, PON and POP concentra- 

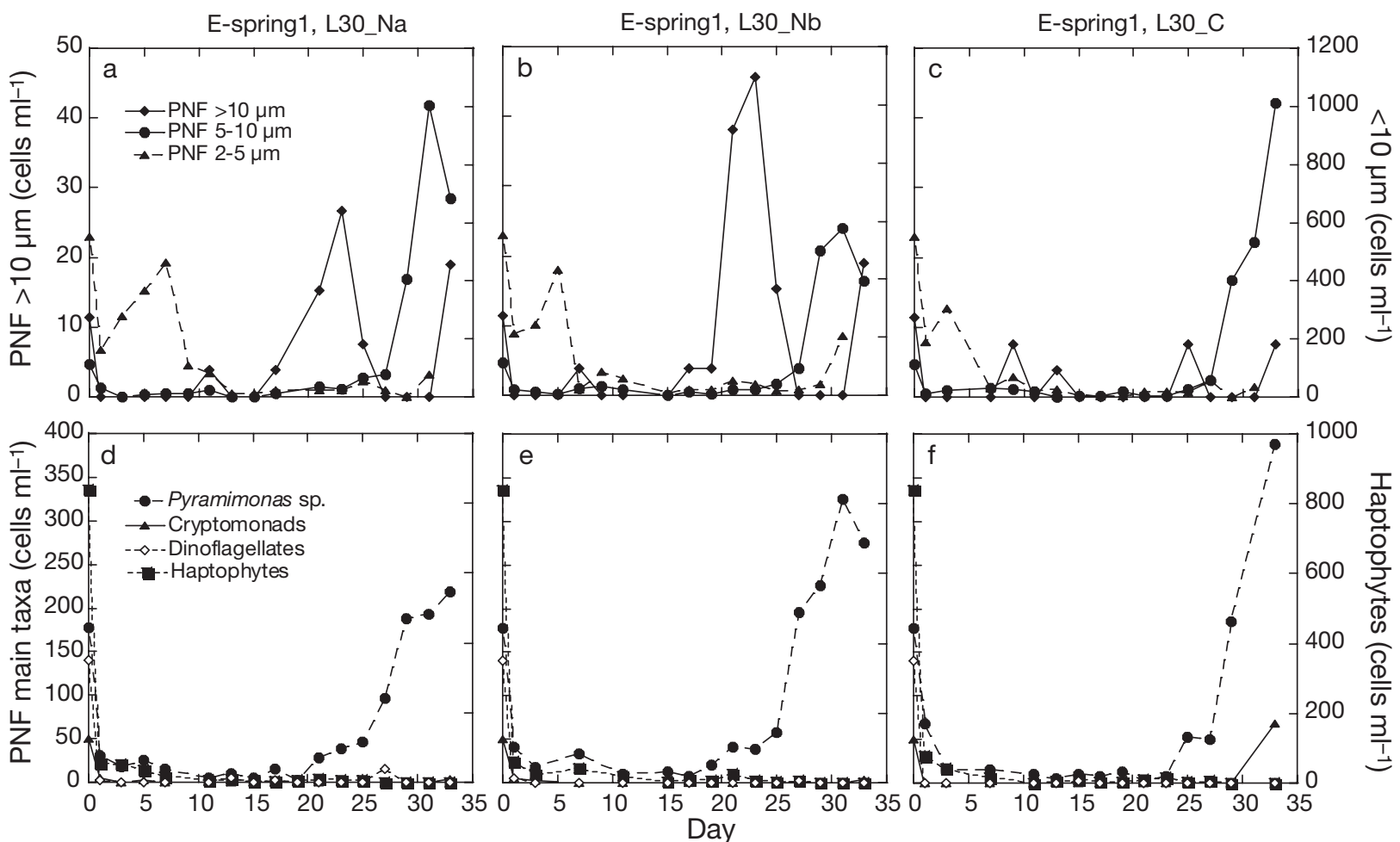

Fig. 3. Temporal evolution of $(\mathrm{a}, \mathrm{b}, \mathrm{c}) 2-5 \mu \mathrm{m}, 5-10 \mu \mathrm{m}$ and $>10 \mu \mathrm{m}$ phototrophic nanoflagellates (PNF, epifluorescence counts) and $(\mathrm{d}, \mathrm{e}, \mathrm{f})$ main PNF taxa for the L30 Na $(\mathrm{a}, \mathrm{d}), \mathrm{L} 30 \mathrm{Nb}(\mathrm{b}, \mathrm{e})$ and L30 C $(\mathrm{c}, \mathrm{f})$ microcosms of E-spring1 (the last data point is missing from the 2-5 $\mu \mathrm{m}$ PNF counts). Note different scales of the right and left ordinate axes. See treatment description in Table 2
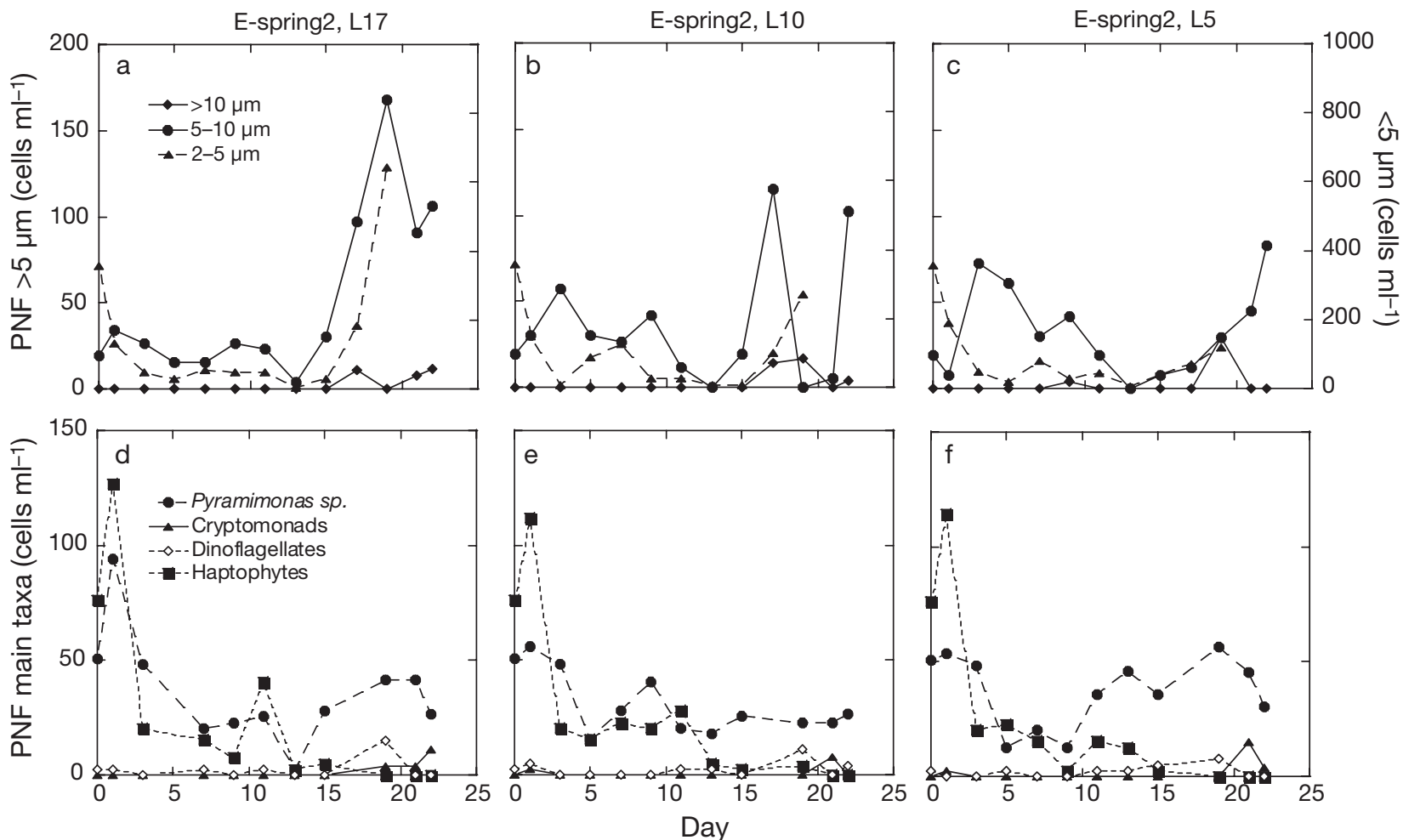

Fig. 4. Temporal evolution of $(\mathrm{a}, \mathrm{b}, \mathrm{c}) 2-5 \mu \mathrm{m}, 5-10 \mu \mathrm{m}$ and $>10 \mu \mathrm{m}$ phototrophic nanoflagellates (PNF, epifluorescence counts) and $(\mathrm{d}, \mathrm{e}, \mathrm{f})$ main PNF taxa for the L17 $(\mathrm{a}, \mathrm{d}), \mathrm{L} 10(\mathrm{~b}, \mathrm{e})$ and L5 $(\mathrm{c}, \mathrm{f})$ microcosms of E-spring2 (the last 2 data points are missing from the 2-5 $\mu \mathrm{m}$ PNF counts). Note different scales of the right and left ordinate axes. See treatment description in Table 2 

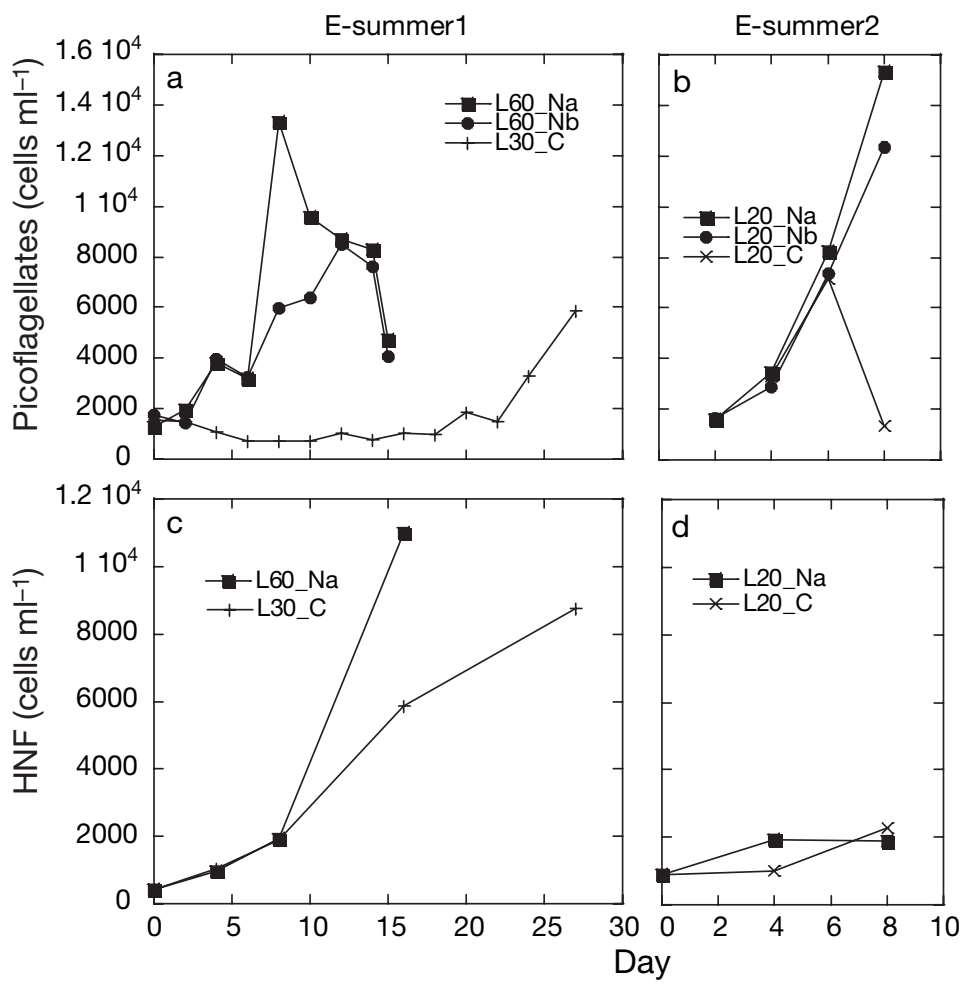

Fig. 5. Temporal evolution of $(\mathrm{a}, \mathrm{b})$ autotrophic picoflagellates and (c, d) heterotrophic nanoflagellates (HNF) for the L60_Na and L30_C microcosms of E-summer1 and the L20_Na $(\mathrm{a}, \mathrm{c})$ and L_20C $(\mathrm{b}, \mathrm{d})$ microcosms of E-summer2. See treatment descriptions in Table 2

tions in the different experiments is given in Table 3. Only 3 of the treatments (L60_N of E-spring1 and Esummer1, and L20_C of E-summer2) showed apparent consumption of DIN. The rest of the treatments had final DIN concentrations that were 0.1 to $2.41 \mathrm{mmol}$ $\mathrm{m}^{-3}$ higher than the initial concentration. This appar- ent lack of utilisation was also found for phosphate (M. Estrada et al. unpubl. data). These findings apparently contradict the observation of increased chl $a$ in most treatments (except in the control of E-spring1 [L60_C] and the medium [L10] and low light [L5] treatments of E-spring2) and increased POC, PON and POP in all bottles.

\section{DISCUSSION}

In the spring experiments, enclosure and provision of light to under-ice phytoplankton resulted in drastic changes in the composition of the community. The highest PAR level used in E-spring1 $\left(60 \mu \mathrm{mol}\right.$ photons $\left.\mathrm{m}^{-2} \mathrm{~s}^{-1}\right)$ induced a decline in chl a concentrations and population densities of the autotrophic picoand nanoflagellates that dominated the initial assemblage (mainly haptophytes and flagellates in the $2-5 \mu \mathrm{m}$ size range, most of the latter possibly Micromonas sp.). A less marked initial decrease in chl $a$ and flagellate concentrations also occurred in the L30 treatment of E-spring1 and the L5, L10 and L17 treatments of E-spring2 $\left(5,10\right.$ and $17 \mu \mathrm{mol}$ photons $\mathrm{m}^{-2}$ $\mathrm{s}^{-1}$, respectively), although picoflagellates did not show an initial decline in E-spring2. After these initial changes, heterotrophic flagellates and the different categories of autotrophic flagellates showed marked population fluctuations. Abundance maxima of phototrophic flagellates were often followed by peaks of heterotrophic flagellates (compare Figs. 2a \& 3a,b,c with Fig. 2c and Figs. 2b \& 4a,b,c with Fig. 2d), suggesting predator-prey relationships

Table 3. Experiment duration, difference between final and initial chlorophyll a concentrations $(\Delta \mathrm{Chl} a)$, initial and final concentrations of dissolved inorganic nitrogen (DIN = nitrate + nitrite + ammonium), POC, PON and POP. Values are means of 1 to 4 determinations. ${ }^{*}$ Calculated by adding initial concentrations to the water and estimating increase after nutrient amendment. ND: no data

\begin{tabular}{|c|c|c|c|c|c|c|c|c|c|c|c|}
\hline Expt & Treatment & $\begin{array}{c}\text { Duration } \\
\text { (d) }\end{array}$ & $\begin{array}{c}\Delta \mathrm{Chl} \mathrm{a} \\
\left(\mathrm{mg} \mathrm{m}^{-3}\right)\end{array}$ & $\begin{array}{l}\text { Initial } \\
\text { DIN } \\
\text { (mm }\end{array}$ & $\begin{array}{l}\text { Final } \\
\text { DIN } \\
\left.\mathrm{m}^{-3}\right)\end{array}$ & $\begin{array}{l}\text { Initial } \\
\text { POC } \\
\text { (mm }\end{array}$ & $\begin{array}{l}\text { Final } \\
\text { POC } \\
\left.\mathrm{m}^{-3}\right)\end{array}$ & $\begin{array}{r}\text { Initial } \\
\text { PON } \\
\text { (mr }\end{array}$ & $\begin{array}{l}\text { Final } \\
\text { PON } \\
\mathrm{m}^{-3} \text { ) }\end{array}$ & $\begin{array}{l}\text { Initial } \\
\text { POP } \\
\text { (mm }\end{array}$ & $\begin{array}{l}\text { Final } \\
\text { POP } \\
\mathrm{m}^{-3} \text { ) }\end{array}$ \\
\hline E-spring1 & L60_N & 9 & -0.24 & 21.34 & 16.63 & 3.42 & 4.85 & 0.43 & 0.67 & 0.025 & 0.066 \\
\hline E-spring1 & L60_C & 9 & -0.25 & 2.37 & 2.49 & 3.42 & 6.75 & 0.43 & 0.59 & 0.025 & 0.099 \\
\hline E-spring1 & L30_N & 33 & 1.87 & 17.14 & 19.55 & 3.42 & 10.21 & 0.43 & 1.21 & 0.025 & 0.041 \\
\hline E-spring1 & L30_C & 33 & 0.88 & 2.42 & 2.56 & 3.42 & 12.58 & 0.43 & 1.21 & 0.025 & 0.062 \\
\hline E-spring2 & $\mathrm{L} 1 \overline{7}$ & 21 & 0.05 & 1.54 & 2.40 & 2.49 & 7.50 & 0.25 & 0.77 & ND & 0.049 \\
\hline E-spring2 & L10 & 21 & -0.10 & 1.54 & 2.41 & 2.49 & 6.39 & 0.25 & 0.83 & ND & 0.051 \\
\hline E-spring2 & L5 & 21 & -0.16 & 1.54 & 2.16 & 2.49 & 6.74 & 0.25 & 0.60 & ND & 0.041 \\
\hline E-summer1 & L60_N & 15 & 35.21 & $16.36^{*}$ & 0.45 & 18.85 & 227.81 & 1.96 & 20.00 & 0.190 & 1.243 \\
\hline E-summer1 & L30_C & 27 & 18.30 & 0.24 & ND & 19.17 & 58.33 & 2.32 & 10.20 & 0.225 & 0.687 \\
\hline E-summer2 & L20_N & 8 & 6.07 & 23.27 & 23.40 & 6.04 & 15.35 & 1.07 & 2.86 & ND & 0.131 \\
\hline E-summer2 & L20_C & 8 & 1.21 & 1.41 & 1.12 & 6.04 & 10.62 & 1.07 & 1.90 & ND & 0.088 \\
\hline
\end{tabular}



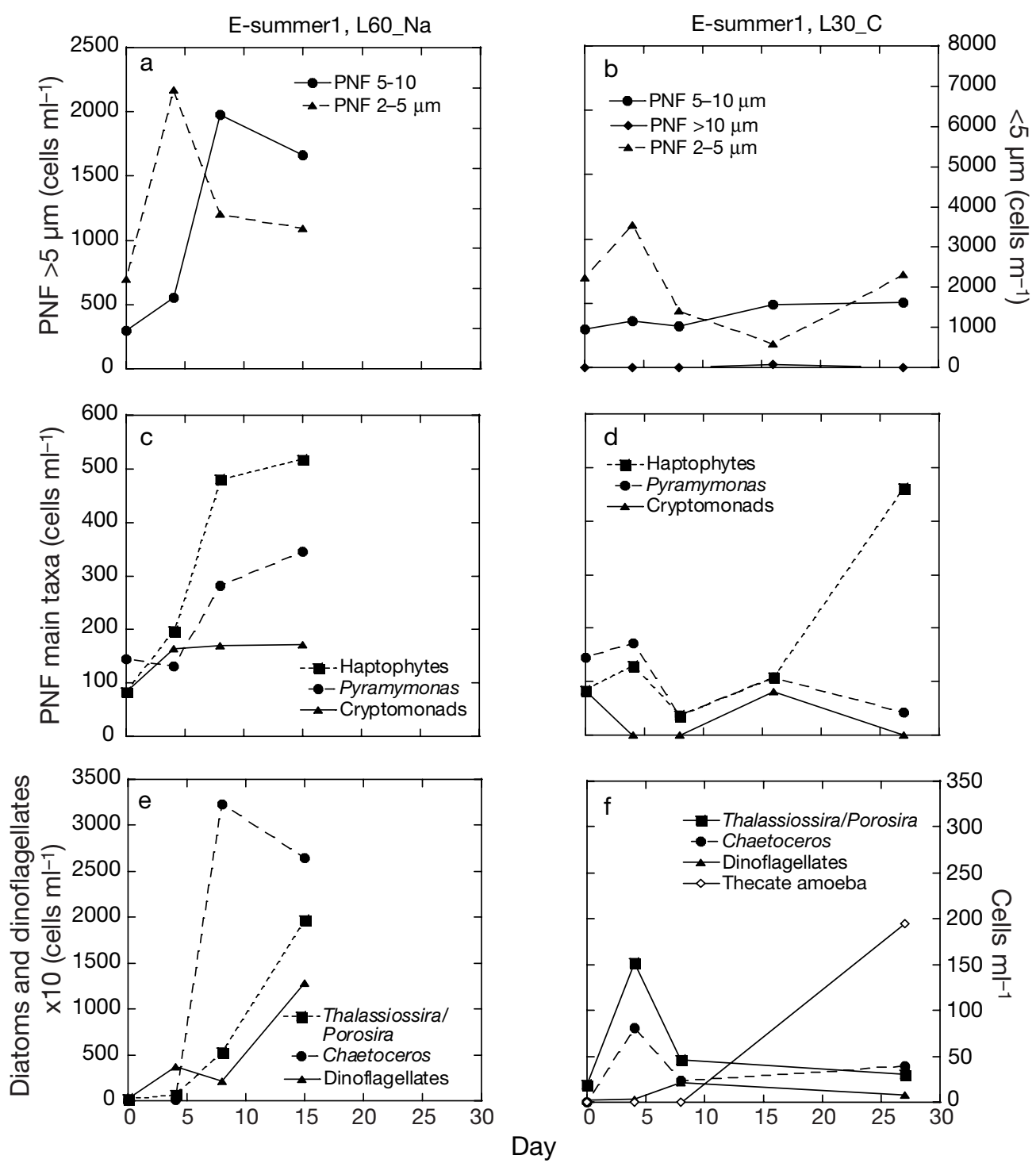

Fig. 6. Temporal evolution of $(\mathrm{a}, \mathrm{b}) 2-5 \mu \mathrm{m}, 5-10 \mu \mathrm{m}$ and $>10 \mu \mathrm{m}$ (when present) phototrophic nanoflagellates (PNF, epifluorescence counts), (c,d) main PNF taxa and (e,f) main phytoplankton taxa (enumerated by inverted microscopy) for the L60_Na (a,c,e) and L30_C $(b, d, f)$ microcosms of E-summer1. Note the different scales of the right and left ordinate axes of (a) and (b) and the multiplication by 10 of dinoflagellate numbers in (e). See treatment description in Table 2

that superimposed their effects on those of environmental factors such as light or nutrients.

The light levels used in the E-spring1 experiment (30 and $60 \mu \mathrm{mol}$ photons $\mathrm{m}^{-2} \mathrm{~s}^{-1}$ ) fell within the range of optimal irradiances (the PAR at which the maximum rate of photosynthesis is observed) reported by Cota \& Smith (1991) for short-term experiments with ice algae and polar phytoplankton. Strong photoinhibition from these PAR levels was not anticipated, but examination by epifluorescence microscopy of samples taken during the first days after enclosure (M. Estrada pers. obs.) showed a strong decline of chloroplast fluorescence in some autotrophic taxa (especially in small hapto- phytes), suggesting potentially deleterious effects of the light levels used on strongly shade-adapted organisms (Ban et al. 2006). Presumably, dark survival of haptophytes and other under-ice microalgae endowed with prominent chloroplasts may have been aided by mixotrophy (Jones et al. 1994), which may include osmotrophy (uptake of dissolved organic matter) or phagotrophy (engulfment of organic particles). Mixotrophy is common in marine and freshwater phytoplankton and numerous studies (many of them in continental waters) highlight their importance in polar environments (Horner \& Alexander 1972, LaybournParry \& Marshall 2004). 

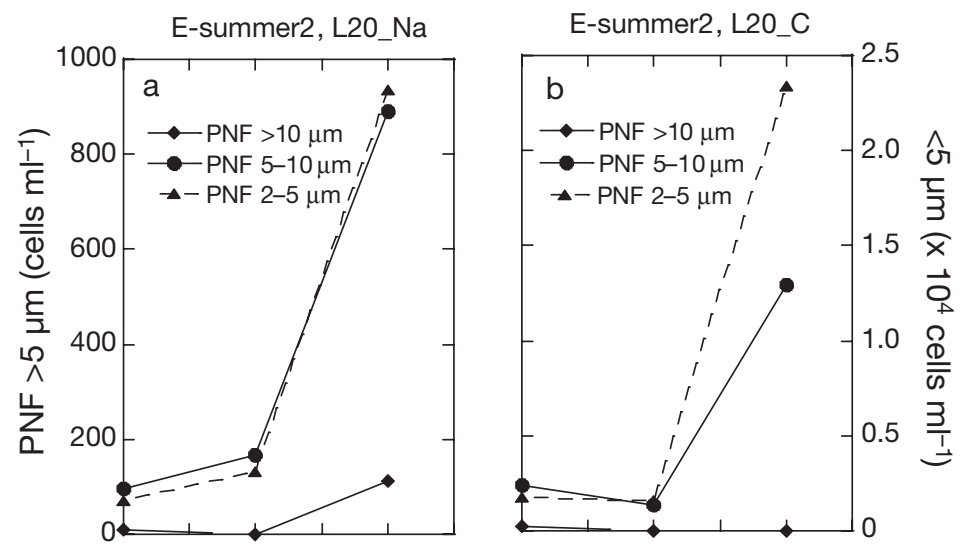

fluorescence counts resulting from a low chl a fluorescence per cell, although the coincident decreases in heterotrophic protists suggest the occurrence of some initial cell mortality. Rough calculations of chl a content per biovolume (chl a/biovol), taking the sum of autotrophic pico- and nanoflagellate biovolumes as total biovolume (as estimated in Terrado et al. 2008), indicate that cell decline between Days 0 and 1 of the L60 and L30 treatments of E-spring1 was accompanied by an average increase of chl a/biovol of $\sim 5$ to 16-21 pg $\mathrm{mm}^{-3}$. This observation supports a dominant contribution of autotrophic cell
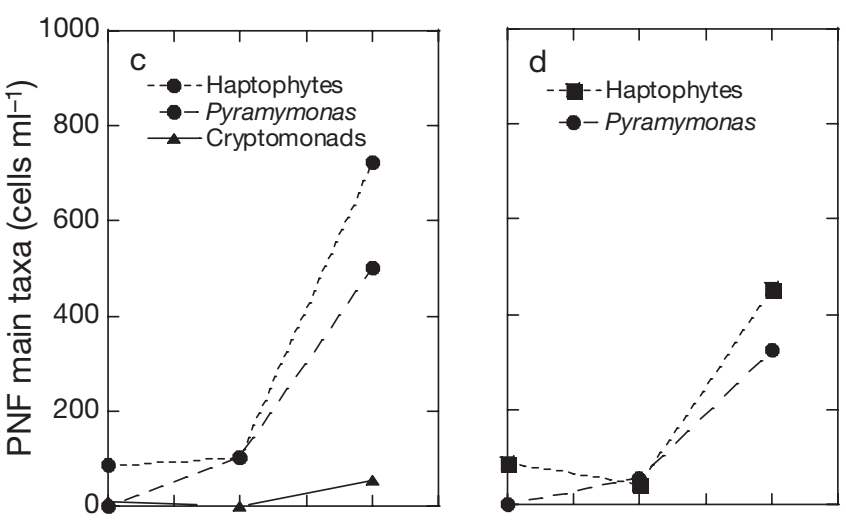
loss, as the chl a/biovol would have decreased as a result of photoacclimation to higher PAR than that experienced in situ. Over the next $4 \mathrm{~d}$, average chl a/biovol went

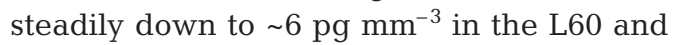

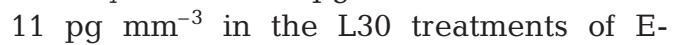
spring1, with the lower values for L60 suggesting a photoacclimation effect. In Espring2, chl a/biovol increased from $20 \mathrm{pg}$ $\mathrm{mm}^{-3}$ to $21-32 \mathrm{pg} \mathrm{mm}^{-3}$ between Days 0 and 1 , suggesting a moderate effect of cell mortality rather than photoacclimation in the initial chl a reduction. From Days 1 to 5, chl a/biovol increased to $29 \mathrm{pg} \mathrm{mm}^{-3}$ in the L17 and decreased to 21 and $15 \mathrm{pg} \mathrm{mm}^{-3}$, respectively, in the L10 and the L5-a pattern of variability inconsistent with an effect of the irradiance level on photoacclimation. In later phases of both spring experiments, chl a/biovol (data not shown) showed wide fluctuations presumably due to a combination of photoacclimation and changes in the dominant organisms. Similar conclusions could be reached from the changes in chl a/ cell (data not shown). However, the interpretation of the chl a/biovol or chl a/cell variability must be taken with caution, not only due to the range of cell sizes or to possible inaccuracies in the calculation of biovolume, but also because of changes in physiological condition and taxonomic composition that were occurring in the microcosms.

Due to logistic constraints, we did not have a treatment with irradiances similar to those received by under-ice communities in situ

The initial chl a decrease in the spring experiments was partly due to autotrophic cell losses, as shown by the drop in pico- and nanoflagellates between Days 0 and 3 in E-spring 1 and in the $2-5 \mu \mathrm{m}$ nanoflagellate category in E-spring2. Part of this decline may also be due to underestimation of autotrophic cells in the epi$\left(\sim 0.5 \mu \mathrm{mol}\right.$ photons $\left.\mathrm{m}^{-2} \mathrm{~s}^{-1}\right)$. However, the similarity of the initial changes for the lowest PAR levels (L17, L10 and L5 of E-spring2), and the finding that heterotrophic flagellates also showed an initial decrease (Fig. 2c,d) suggest that, in addition to light, enclosure itself may have also affected the initial community of 
the spring experiments. During sampling of the initial inoculum, all manipulations were carried out with care to minimize temperature changes and avoid exposure to environmental light. However, as with all incubations, enclosure of the planktonic community may have affected a variety of other factors in addition to the variables manipulated in the treatments (PAR or major nutrient concentrations). These other factors may include exchanges of materials and the occurrence of certain predators (like relatively large zooplankters), which not only consume smaller grazers and phytoplankton cells but also release metabolites.

The results of the second spring experiment (Espring2), which showed sustained chl a increase and highest cell abundances in the bottles exposed to $17 \mu \mathrm{mol}$ photons $\mathrm{m}^{-2} \mathrm{~s}^{-1}$ PAR for $19 \mathrm{~h}(\sim 1.16 \mathrm{~mol}$ photons $\mathrm{m}^{-2} \mathrm{~d}^{-1}$ ), suggest that $1.16 \mathrm{~mol}$ photons $\mathrm{m}^{-2} \mathrm{~d}^{-1}$ would be close to the irradiance at which gross primary production equalled community losses in the experimental bottles. Although this value applies to the flagellate-dominated community that grew in our bottles, it falls within the range for diatom-dominated assemblages of 0.75 and $1.3 \pm 0.3 \mathrm{~mol}$ photons $\mathrm{m}^{-2} \mathrm{~d}^{-1}$ reported by Wetz et al. (2004) off Oregon and Siegel et al. (2002) for the North Atlantic, respectively. However, it is somewhat lower than the $1.9 \pm 0.3 \mathrm{~mol}$ photons $\mathrm{m}^{-2} \mathrm{~d}^{-1}$ found by Tremblay et al. (2006) for the North Water Polynya of the Arctic Ocean. Ban et al. (2006), using a pulse amplitude modulation fluorometer (Phyto-PAM), measured a 'minimum saturation irradiance' $\left(\mathrm{E}_{\mathrm{k}}\right)$ of $10 \mu \mathrm{mol}$ photons $\mathrm{m}^{-2} \mathrm{~s}^{-1}$ for ice algae and phytoplankton samples taken from Franklin Bay during the CASES project between 23 and 30 May 2004. This $E_{k}$ value is not consistent with the observed lack of algal growth at the $10 \mu \mathrm{mol}$ photons $\mathrm{m}^{-2} \mathrm{~s}^{-1}$ treatment of E-spring2. The discrepancy could partly be due to differences in the spectral output between the PAM fluorometer and the light sources used in our experiments. The Phyto-PAM uses LEDs that generate pulsed light at wavelengths of 470 (blue), 520 (green), 645 (light red) and $665 \mathrm{~nm}$ (dark red). According to the Phyto-PAM manual (Anonymous 2003), the higher absorption in red light compared to white light makes this arrangement $\sim 20 \%$ more effective than white light sources. Ban et al. (2006) also reported that photoinhibition in their samples was only observed above $30 \mu \mathrm{mol}$ photons $\mathrm{m}^{-2} \mathrm{~s}^{-1}$.

Our results are in basic agreement with those of Terrado et al. (2008), who found that the phototrophic increase of incubated under-ice communities was responsive to improved irradiance conditions but not to nutrient enrichment. However, unlike the present study, Terrado et al. (2008) did not report an initial biomass (biovolume) decrease, probably due to the fact that these authors started sampling their cultures $4 \mathrm{~d}$ after water collection, when most of the cell number decline had already occurred. Another discrepancy with respect to our spring results is the increase in diatom biomass in Terrado et al. (2008), although bloom concentrations were not reached. However, most of their diatoms were colonies of Nitzschia spp., which are typical ice diatoms but are not prominent in the late-spring bloom in the region. Terrado et al. started their experiment on 23 April, only a few days after our E-spring1 and E-spring2 experiments, but community changes were occurring rapidly at this time; thus, it is possible that variation in the initial inoculum, together with differences in the light treatment and experimental setup, could have contributed to the disparity in ice-diatom response. Prefiltration through a $200 \mu \mathrm{m}$ mesh could have decreased the contribution of relatively large diatoms to the inoculum of E-spring2, but this is unlikely to be the main cause of the lack of diatom growth in our experiments, because the results of the L17 (light-sufficient) treatment of Espring2 were comparable to those of the L30 treatment of E-spring1, in which prefiltration was not used. Other reasons for the lack of growth of planktonic diatoms in our experiments are discussed below.

Prasinophytes like Micromonas spp. have been found repeatedly in ice and water column microalgal assemblages (Sherr et al. 2003, Lovejoy et al. 2007). Pyramimonas spp. have also been found in these communities in the region (Różańska et al. 2008), but they were not as dominant as the relatively large (8 to $9 \mu \mathrm{m}$ ) Pyramimonas sp. that grew at the end of the spring experiments. Proliferation of the latter might be explained by its relatively large size and the lack of adequate protist predators in the experimental bottles. Although several species of pennate diatoms, like Nitzschia frigida and Navicula pelagica, were abundant in the ice (M. Estrada pers. obs.) and could be found in the under-ice waters used as inoculum in spring, these diatoms did not thrive in the experimental bottles. This was also the case with Chaetoceros spp. and Thalassiosira/Porosira, but these were only present at low concentrations in net samples from spring under-ice water. The phytoplankton assemblage, dominated by Pyramimonas sp. and other flagellates, growing at the end of the spring experiments was different from that found at about this time (5 May) in Bathurst Polynya, which showed a rich diatom community with high abundance of the Thalassiosira/Porosira complex and Chaetoceros spp. (M. Estrada pers. obs.). The growth failure of these diatoms in the spring experiments could be due to their initial concentrations being too low to generate a viable population. This low diatom abundance may also explain the difference between our results and those of Wetz et al. (2004), who reported diatom blooms in experiments carried out on shipboard incubators with phytoplank- 
ton collected from the benthic boundary layer $(80 \mathrm{~m}$ depth) off Oregon. Diatom growth in our experiments might have also been hindered by other endogenous or exogenous factors. Eilertsen et al. (1995) reported that germination and perhaps also subsequent growth of resting spores of typical spring bloom diatoms (including Chaetoceros spp. and Thalassiosira spp.) from 2 fjords near Tromsø (Norway) were controlled by photoperiod. These authors found that some species failed to grow when exposed to low light levels $(2 \mu \mathrm{mol}$ photons $\mathrm{m}^{-2} \mathrm{~s}^{-1}$ ) or to daylengths shorter than $13 \mathrm{~h}$. However, these daylength limits were exceeded after the first $9 \mathrm{~d}$ in E-spring1 and in E-spring2 (where at least the higher light level should have been sufficient). It is also possible that proliferation of the centric diatoms typical of open-water spring blooms depends on ice breakup and subsequent mixing of the water column that causes resuspension of resting forms from the sediments and their entrainment into the photic zone.

In contrast with the spring experiments, phytoplankton in the summer setup grew immediately after enclosure. The dominant phytoplankton taxa in our summer experiments were the Thalassiosira/Porosira complex and Chaetoceros spp., which were also dominant in the Bathurst Polynya samples mentioned above and have been reported as major components of the spring bloom in the Chukchi Sea (Hill et al. 2005) and in other Arctic regions (von Quillfeldt 2000). As in the spring experiments, the coincidence of the increase in heterotrophic with the decrease in autotrophic flagellates (compare Fig. 5c with Fig. 5a) suggested a predatorprey relationship. The thecate amoeba (Difflugia sp.?) that grew in the L_30C bottle of E-summer1 (Fig. 6f) appeared to have dramatically controlled the autotrophic populations, although it is difficult to extrapolate this observation to natural conditions.

Our results are in agreement with the findings of Sherr et al. (2003), Carmack et al. (2004) and Tremblay et al. (2006), who indicated that phytoplankton growth was light-limited in early spring and nutrient-limited thereafter. Nutrient addition in the first spring experiment had only a limited effect on phytoplankton growth within the range of phytoplankton biomass produced in this experiment. After Day 15, chl a concentration in E-spring1 was somewhat higher in the L30_N bottles than in the control (L30_C) but the rate of increase in chl a concentration was similar for all bottles and the experiment had to be terminated while the phytoplankton community was still growing exponentially. The situation was very different in summer, when phytoplankton growth in the control bottles slowed down soon after the beginning of the experiments (Fig. 1C,d). Interpretation of E-summer1 is complicated because the bottle without nutrient additions (L30_C) had also been exposed to lower irradiance than the others (L60_N). Taking into account the rapid growth observed in the L20_N bottles of E-summer2, which were incubated under lower irradiance than the L30 bottle of E-summer1, it seems likely that the limitation of growth in L30_C was due to nutrient exhaustion rather than light limitation, although this evidence is not conclusive due to an inadequate number of control bottles. E-summer2 did not last long enough to reach a stationary phase, but there was a clear effect of nutrient addition on the growth rate of the autotrophic community. In the spring experiments, nutrient treatments did not affect the response of heterotrophic flagellates as happened with the autotrophs. Only in the summer experiments were the population densities of heterotrophic flagellates higher in the nutrientamended bottles than in the control ones.

The molar ratios of the differences between final and initial POC and PON ( $\triangle \mathrm{POC}: \triangle \mathrm{PON}$ ) and final and initial particulate organic nitrogen and phosphorus $(\triangle \mathrm{PON}: \triangle \mathrm{POP})$ resulting from the different experiments (M. Estrada et al. unpubl. data) were rather variable and difficult to interpret, partly because the changes in biomass were too small to make useful calculations in most treatments. However, examination of Table 3 reveals some intriguing questions regarding nutrient stoichiometry. Chl a increases were accompanied by POC, PON and POP production, although in the summer experiments, the PON increase was generally low relative to that of chl a $(<1 \mathrm{mmol}$ of PON per $\mathrm{mg}$ of $\mathrm{chl}$ a). However, in E-summer1, when chl a peaked at $\sim 43 \mathrm{mg} \mathrm{m}^{-3}$, there appeared to be a marked drawdown of DIN, with a matching increase in PON. We don't have an explanation for the low PON to chl a ratios, but the lack of DIN consumption in some of the experiments suggests the likely presence of organic sources of $\mathrm{N}$. The main possibilities include remineralization of DON, phagotrophy, direct utilization of DON by autotrophs, or a combination of all these processes (Kattner \& Becker 1991, Bronk et al. 2006). We have no data on DON concentrations during our cruise leg, but measurements were carried out in different parts of the Beaufort Sea during the following legs (Simpson et al. 2008) at different periods between 13 May and 31 August 2004. Simpson et al. (2008) found that DON and DOP concentrations were elevated in surface waters during the phytoplankton bloom and postbloom phases, and attributed the relatively high (average of $5 \mathrm{mmol} \mathrm{m}^{-3}$ ) and variable DON concentrations to the proximity of the Mackenzie River outflow. In a survey of nutrients and organic matter across the Mackenzie estuary in July to August 2004, Emmerton et al. (2008) found DON concentrations of $17.1 \mathrm{mmol} \mathrm{m}^{-3}$ on the Mackenzie shelf, which are among the highest reported for the Arctic Ocean. Preferential use of DON at concentration levels similar to those measured by 
Simpson et al. (2008) or Emmerton et al. (2008) could explain the discrepancy in DIN drawdown and chl a and organic matter build-up. Other authors (Skoog et al. 2001) reported that DON was the largest fraction of total dissolved nitrogen in a region encompassing the Northeast Water Polynya. The importance of DON sources for Arctic phytoplankon was shown by Harrison et al. (1985), who reported that urea accounted for as much as $80 \%$ of the nitrogen uptake in the eastern Canadian Arctic and by Fouilland et al. (2007), who found that phytoplankton accounted for a larger fraction of urea uptake than heterotrophic bacteria. In contrast, DON sources appeared to play a smaller role in microcosm experiments carried out with phytoplankton communities of temperate waters, which showed a marked consumption of DIN (Granéli et al. 1999, Estrada et al. 2003). Another process affecting DIN and DON variability is bacterial activity, which was proposed by Tremblay et al. (2002) to explain a slight increase in the nitrate inventory between mid-June and mid-July in waters from below the mixed layer of the Baffin Bay Waters sector of the North Water Polynya. As discussed above, mixotrophy may also be important for chl a-containing flagellates in polar waters.

In our experiments, enclosure and provision of light during the ice-covered period of the year induced a series of fluctuations in populations of auto- and heterotrophic microbial groups. The sequence of events reflected initial cell losses of major autotrophic flagellate groups present in the inoculum, presumably caused by light and enclosure effects, followed by population peaks of some picoflagellate groups. The decline in these peaks appeared to be mainly due to microzooplankton predators, which showed population increases coinciding with autotrophic population decreases, since competition for light (there was no appreciable self-shading) or nutrients seemed unlikely. As noted above, the dominance of Pyramimonas sp. at the end of E-spring1 was possibly related to the lack of grazers of adequate size to control it. The response of the Arctic planktonic community in our spring experiments is different from that found in similar experiments in coastal temperate areas where, when nutrients are available, the typical outcome is an initial proliferation of diatoms, followed by other, slower-growing phytoplankton groups as found in our summer experiments (Estrada et al. 2003). The lack of diatom growth in our spring incubations may have been due to the low abundance of typical bloom diatoms in our inocula. However, the delay in the start of microalgal biomass increase after the initial changes may reflect the combined effects of a lack of preadaptation of under-ice phytoplanton to the sudden increase of PAR, and strong predation control by micro- zooplankton. Very different population dynamics occurred in the summer experiments during the seasonal diatom bloom of the open waters. The chl $a$ and nutrient changes in the L60_N treatments of E-summer1 suggest that the overall stagnation of autotrophic growth was linked to nutrient and perhaps light limitation, rather than to predation effects. In L30_C, where grazing by Difflugia sp.? and other consumers contributed to the demise of some autotrophic populations, low inorganic nutrient concentrations might have limited phytoplankton growth from the beginning of the experiment. We must note here that several phytoplankton groups showed some initial increase in the control treatments of our summer experiments, although nutrient concentrations were the same as those in situ. This is a general observation in microcosm experiments (Estrada et al. 2003) when available nutrients in the medium (or in cellular reserves) allow it. The reasons are not completely clear but are likely to involve various combinations of reduced physical dispersion losses, improved light regime due to absence of deep mixing, and changes in predation pressure linked to the exclusion of relatively large grazers.

Our experiments show that enclosure and provision of sufficient light to the under-ice microbial community induced a 2 wk period of complex community changes followed by an exponential increase in some autotrophic nanoflagellate populations and in chl a concentration. Nutrient additions did not affect the net rate of phytoplankton accumulation. These results reveal a tight adaptation of the microbial community of under-ice waters to the ecological conditions of this environment.

Acknowledgements. Financial support for this study was provided by grants from the Generalitat de Catalunya (DURSI 2003ACES00029/ANT), the Spanish Ministerio de Educación y Ciencia (REN2002-11565-E/ANT), and the Natural Sciences and Engineering Research Council of Canada (NSERC) through project CASES (Canadian Arctic Shelf Exchange Study) under the overall direction of L. Fortier. M.M.S. had a CSIC-I3P postdoctoral contract funded by the Fondo Social Europeo. We thank S. Demers and W. F. Vincent for the opportunity to participate in the CASES project, and M. Gosselin, C. Lovejoy, C. Nozais, C. Pedrós-Alió, R. Terrado, D. Vaqué, and officers and crew of the CCGS 'Amundsen' for their collaboration and support. M. Coll, J. Masmitjà, S. Méndez, I. Ontoria, A. Sabata, E. Tarragó, R. Ventosa and G. Vila provided technical assistance in the processing and analysis of the picoplankton, flagellate and nutrient samples.

\section{LITERATURE CITED}

Anderson MR, Rivkin RB (2001) Seasonal patterns in grazing mortality of bacterioplankton in polar oceans: a bipolar comparison. Aquat Microb Ecol 25:195-206

Anonymous (2003) Phytoplankton analyzer Phyto-PAM and Phyto-Win software V1.45, 2nd edn. Heinz Walz, Effeltrich 
Ban A, Aikawa S, Hattori H, Sasaki H and others (2006) Comparative analysis of photosynthetic properties in ice algae and phytoplankton inhabiting Franklin Bay, the Canadian Arctic, with those in mesophilic diatoms during CASES 2003-3004). Polar Biosci 19:11-28

Booth BC, Larouche P, Bélanger S, Klein B, Amiel D, Mei ZP (2002) Dynamics of Chaetoceros socialis blooms in the North Water. Deep-Sea Res II 49:5003-5025

Bronk DA, See JH, Bradley P, Killberg L (2006) DON as a source of bioavailable nitrogen for phytoplankton. Biogeosciences Discuss 3:1247-1277

- Carmack EC, Macdonald RW, Jasper S (2004) Phytoplankton productivity on the Canadian Shelf of the Beaufort Sea. Mar Ecol Prog Ser 277:37-50

Cota GF, Smith REH (1991) Ecology of bottom ice algae. Comparative physiology. J Mar Syst 2:297-315

Eilertsen HC, Sandberg S, Tøllefsen H (1995) Photoperiodic control of diatom spore growth: a theory to explain the onset of phytoplankton blooms. Mar Ecol Prog Ser 116: 303-307

Emmerton CA, Lesack LFW, Vincent WF (2008) Nutrient and organic matter patterns across the Mackenzie River, estuary and shelf during the seasonal recession of sea ice. J Mar Syst 74:741-755. doi:10.1016/j.jmarsys.2007.10.001

Estrada M, Berdalet E, Vila M, Marrasé C (2003) Effects of pulsed nutrient enrichment on enclosed phytoplankton: ecophysiological and successional responses. Aquat Microb Ecol 32:61-71

Fouilland E, Gosselin M, Rivkin RB, Vasseur C, Mostajir B (2007) Nitrogen uptake by heterotrophic bacteria and phytoplankton in Arctic surface waters. J Plankton Res 29: 369-376

Gradinger RR, Baumann MEM (1991) Distribution of phytoplankton communities in relation to the large-scale hydrographical regime in the Fram Strait. Mar Biol 111:311-321

Granéli E, Carlsson P, Turner JT, Tester PA, Béchemin C, Dawson R, Funari E (1999) Effects of N:P:Si ratios and zooplankton grazing on phytoplankton communities in the northern Adriatic Sea. I. nutrients, phytoplankton biomass and polysaccharide production. Aquat Microb Ecol 18: 37-54

Grasshoff K, Ehrhardt M, Kremling K (1999). Methods of seawater analysis, 3rd edn. Verlag Chemie, Weinheim, Germany

> Guillard RRL, Ryther JH (1962) Studies of marine planktonic diatoms, 1. Can J Microbiol 8:229-239

Harrison WG, Head EJH, Conover RJ, Longhurst AR, Sameoto DD (1985) The distribution and metabolism of urea in the eastern Canadian Arctic. Deep-Sea Res I 32: 23-42

Hill V, Cota G, Stockwell D (2005) Spring and summer phytoplankton communities in the Chukchi and eastern Beaufort Seas. Deep-Sea Res II 52:3369-3385

Horner R, Alexander V (1972) Algal populations in Arctic sea ice: an investigation of heterotrophy. Limnol Oceanogr 17 : $454-458$

Horner RA, Schrader GC (1982) Relative contributions of ice algae, phytoplankton and benthic microalgae to primary production in nearshore regions of the Beaufort Sea. Arctic 35:485-503

- Hsiao SIC, Foy MG, Kittle DW (1977) Standing stock, community structure, species composition, distribution, and primary production of natural populations of phytoplankton in the southern Beaufort Sea. Can J Bot 55:685-694

Hu S, Smith WO (1998) The effects of irradiance on nitrate uptake and dissolved organic nitrogen release by phytoplankton in the Ross Sea. Cont Shelf Res 18:971-990
Jones HLJ, Leadbeater BSC, Green JC (1994) Mixotrophy in haptophytes. In: Green C, Leadbeater BSC (eds) The haptophyte algae. Clarendon Press, Oxford, p 247-263

Kattner G, Becker H (1991) Nutrients and organic nitrogen compounds in the marginal ice zone of the Fram Strait. J Mar Syst 2:385-394

> Laybourn-Parry J, Marshall WA (2003) Photosynthesis, mixotrophy and microbial plankton dynamics in two high Arctic lakes during summer. Polar Biol 26:517-524

Longhurst A (1998) Ecological geography of the sea. Academic Press, New York

Lovejoy C, Legendre L, Martineau MJ, Bâcle J, von Quillfeldt $\mathrm{CH}$ (2002) Distribution of phytoplankton and other protists in the North Water. Deep-Sea Res II 49:5027-5047

Lovejoy C, Vincent WF, Bonilla S, Roy S and others (2007) Distribution, phylogeny and growth of cold-adapted picoprasinophytes in Arctic Seas. J Phycol 43:78-89

Porter KG, Feig YS (1980) The use of DAPI for identifying and counting aquatic microflora. Limnol Oceanogr 25:943-948

> Różańska M, Poulin M, Gosselin M (2008) Protist entrapment in newly formed sea ice in the Canadian Beaufort Sea. J Mar Syst 74:887-901

> Rysgaard S, Nielsen TG, Hansen BW (1999) Seasonal variation in nutrients, pelagic primary production and grazing in a high-Arctic coastal marine ecosystem, Young Sound, Northeast Greenland. Mar Ecol Prog Ser 179:13-25

> Sala MM, Terrado R, Lovejoy C, Unrein F, Pedrós-Alió C (2008) Metabolic diversity of heterotrophic bacterioplankton over winter and spring in the coastal Arctic Ocean. Environ Microbiol 10:942-949

> Sherr EB, Sherr BF (2003) Community respiration/production and bacterial activity in the upper water column of the central Arctic Ocean. Deep-Sea Res I 50:529-542

Sherr EB, Sherr BF, Wheeler PA, Thompson K (2003) Temporal and spatial variation in stocks of autotrophic and heterotrophic microbes in the upper water column of the central Arctic Ocean. Deep-Sea Res I 50:557-571

Siegel DA, Doney SC, Yoder JA (2002) The North Atlantic spring phytoplankton bloom and Sverdrup's critical depth hypothesis. Science 296:730-733

Simpson KG, Tremblay J-É, Gratton Y, Price NM (2008) An annual study of inorganic and organic nitrogen and phosphorus, and silicic acid, in the southeastern Beaufort Sea. J Geophy Res C 113:C07016 doi:10.1029/2007JC004462

Skoog A, Lara R, Kattner G (2001) Spring-summer cycling of DOC, DON and inorganic $\mathrm{N}$ in a highly seasonal system encompassing the Northeast Water Polynya, 1993. DeepSea Res I 48:2613-2629

Smith WO, Gosselin M, Legendre L, Wallace DWR, Daly KL, Kattner G (1991) Importance of Phaeocystis blooms in the high-latitude ocean carbon cycle. Nature 352:514-516

Terrado R, Lovejoy C, Massana R, Vincent WF (2008) Microbial food web responses to light and nutrients beneath Arctic sea ice during the winter-spring transition. J Mar Syst 74:964-977

Throndsen J (1978). Preservation and storage. In: Sournia A (ed) Phytoplankton manual. UNESCO, Paris, p 69-74

Tremblay JÉ, Gratton Y, Fauchon J, Price NM (2002) Climatic and oceanic forcing of new, net and diatom production in the North Water. Deep-Sea Res II 49:4927-4946

Tremblay JÉ, Michel C, Hobson KA, Gosselin M, Price NM (2006) Bloom dynamics in early opening waters of the Arctic Ocean. Limnol Oceanogr 51:900-912

Utermöhl H (1958) Zur Vervollkommung der quantitativen Phytoplankton Methodik. Mitt Int Ver Theor Angew Limnol 9:1-38

Vidal M, Duarte CM (2000) Nutrient accumulation at differ- 
ent supply rates in experimental Mediterranean planktonic communities. Mar Ecol Prog Ser 207:1-11

von Quillfeldt CH (2000) Common diatom species in Arctic spring blooms: their distribution and abundance. Bot Mar 43:499-516

Wang J, Cota GF, Comiso JC (2005) Phytoplankton in the Beaufort and Chukchi Seas: distribution, dynamics and environmental forcing. Deep-Sea Res II 52:3355-3368

$>$ Wells LE, Deming JW (2006) Significance of bacterivory and

Editorial responsibility: Ruben Sommaruga,

Innsbruck, Austria viral lysis in bottom waters of Franklin Bay, Canadian Arctic, during winter. Aquat Microb Ecol 43:209-221

Wetz MS, Wheeler PA, Letelier RM (2004) Light-induced growth of phytoplankton collected during the winter from the benthic boundary layer off Oregon, USA. Mar Ecol Prog Ser 280:95-104

Yentsch DS, Menzel DW (1963) A method for the determination of phytoplankton chlorophyll and phaeophytin by fluorescence. Deep-Sea Res 10:221-231

Submitted: July 8, 2008; Accepted: October 30, 2008

Proofs received from author(s): February 16, 2009 